\title{
Triggering Entrepreneurial Intensions through Experiential Learning in an Open Distance Learning Institution
}

\author{
Tshilidzi Eric Nenzhelele \\ Senior Lecturer, University of South Africa \\ nenzhte@unisa.ac.za
}

Doi:10.5901/mjss.2014.v5n16p199

\begin{abstract}
Entrepreneurship has been earmarked as a major contributor to countries' economy by promoting innovation, competition, and employment. Entrepreneurship is a process and entrepreneurial intention is the first step in the process. No entrepreneurial behaviours happen by accident. Entrepreneurial behaviours are intentionally planned. Therefore, entrepreneurial intentions are the best predictors of entrepreneurial behaviour. It has been established that educational courses in entrepreneurship triggers entrepreneurial intentions. Also, it has been concluded that experiential learning produces entrepreneurs the same way it produces nurses, doctors and engineers. However, there is lack of research that establishes whether other nonentrepreneurship courses influence entrepreneurship intentions of learners. Therefore, the purpose of this study is to establish the influence of business management experiential learning course in open distance learning institution on entrepreneurial intensions of learners. This is a quantitative research and uses a questionnaire to collect data from the respondents.
\end{abstract}

Keywords: entrepreneurship; entrepreneurs; entrepreneurial intentions; experiential learning; open distance learning

\section{Introduction}

Entrepreneurship has been earmarked as a major contributor to countries' economy by promoting innovation, competition, and employment (Gurel, Altinay and Daniele, 2010). Entrepreneurship is a process and entrepreneurial intention is the first step in the process. No entrepreneurial behaviours happen by accident. Entrepreneurial behaviours are intentionally planned. Therefore, entrepreneurial intentions are the best predictors of entrepreneurial behaviour. It has been concluded that experiential learning produces entrepreneurs the same way it produces nurses, doctors and engineers (Dhliwayo, 2008).

Entrepreneurs should start businesses not look for jobs (Southon and West, 2005). However, due to lack of startup capital, most people start by getting a job to raise start-up before they start their businesses (Khodabakhshi and Talebi, 2012). There are many influencing factors to entrepreneurial intensions (Sajjad, Shafi, Dad and Kashmir, 2012). For example, personality traits influence entrepreneurial intentions (Nga and Shamuganathan, 2010). Gurel, Altinay and Daniele (2010) state that people with characteristics such as high propensity for risk taking, tolerance for ambiguity and internal locus of control are more likely to start a new business venture. Also, the environment influence entrepreneurial intentions (Arasti, Pasvishe and Motavaseli, 2012). Research on the influence of entrepreneurship courses on entrepreneurial intentions have been conducted intensively. However, researches on the influence of other nonentrepreneurship courses on entrepreneurial intentions are lacking. Moreover, researches on the influence of experiential learning courses in open distance learning are lacking. The purpose of this study is to establish the influence of administrative practice experiential learning course in open distance learning institution on entrepreneurial intensions of learners. Administrative practice is a module offered at the University of South Africa (UNISA). UNISA is the largest open distance learning university in Africa.

\section{Experiential Learning}

True learning is the result of students' experiences, and the evaluation and reflection of these experiences (Moore, Boyd and Dooley, 2010). Experiential learning unlocks capabilities because it about action rather than just learning theory (Jennings and Wargneir, 2010). Ghose (2010) states that experiential learning can be implemented by educators in varied disciplines to equip students with hand-on experience. Clark and White (2010) conclude that quality university business education program must include an experiential learning component. 
Although there are many definitions of experiential learning, Kolb (1984) is the most quoted. Kolb (1984) defines experiential learning as the process whereby knowledge is created through the transformation of experience. According to Kolb, experiential learning is a four stage process. These stages are depicted in figure 1 and discussed below.

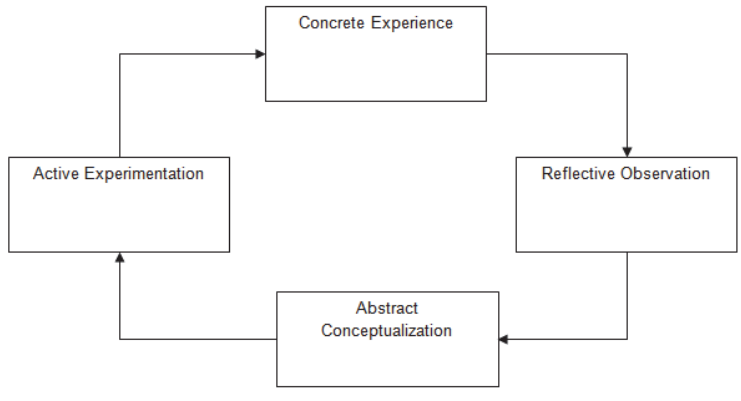

Figure 1: Kolb' Cycle of experiential learning (Adapted from Kolb, 1984)

- Concrete Experience: the learner must be willing and be actively involved in the experience;

- Reflective Observation: the learner must be able to reflect on the experience;

- Abstract Conceptualization: the learner must possess and use analytical skills to conceptualize the experience; and

- Active Experimentation: the learner must possess decision making and problem solving skills in order to use the new ideas gained from the experience.

Experiential learning is categorized into two different types: one which is more personal and informal (e.g. learning from experience that one should always read through an e-mail before sending it) and another type that is a designed learning event with situations to which the learner is intentionally exposed (Vesper, Kartog, Bishara and Reeves, 2010). Experiential learning can take many forms including internships, volunteering to work in a firm and simulation (Clark and White, 2010).

Experiential learning provides many benefits to students, faculties and educational institutions, firms/owner/manager, researchers and government policy makers (Hynes and Richardson, 2007). According to Nevin (2001) experiential learning provide learners with fun, exciting and entertaining way of learning. Experiential learning gives students an opportunity to be real not pretenders (Vincett and Farlow, 2008). In addition, experiential learning create the right atmosphere for learning, put value on students' knowledge, skills and experience, enforce sharing of ideas and increase synergistic learning of participants (Smith, Collins and Hannon 2006).

\subsection{Experiential learning course in administrative management}

The course is entitled "Administrative Practice" because of the experiential learning component in it. This course is offered by the University of South Africa (UNISA) the largest Open Distance Learning (ODL) university in Africa. The purpose of the course is to provide the learners with experiential learning in the national diploma in administrative management. This course prepares students for the work environment.

Upon registration, students receive study materials which include all assignments to be completed. One of the assignments they must complete is the experiential learning project which should be completed in a work environment and submitted to the university for final assessment. Other assignments cover theory on experiential learning. With the help of the university, students are to find a work placement. They are required to spend two months at the work environment. During this period, students are to familiarise themselves with the organisation in which they are placed; learn the information systems in use; use both written and electronic communication; discover the area that require insurance; plan the office environment; learn how administrative function support other organisational functions; learn about quality assurance; ensure that the office observes green principles; expose themselves to facilities management; learn about automated processes in the organisation; learn about ergonomic office; discover how the organisation decorate its offices; learn about buying; and facilitate meetings. In a nutshell, students learn all about administrative management.

Students are provided with a log book which contains all the activities they should complete. After completing each 
activity, students must record evidence of completion in a portfolio of evidence. They are required to attach supporting documents to their portfolio. Also, students are to declare ownership of their portfolio of evidence by attaching a declaration form with a stamp of commissioner of auth. They are to make their portfolio presentable by biding or filing it and get it ready for submission to the university. The portfolio is submitted towards the end of the year for final assessment.

\section{Open Distance Learning}

There has been a tremendous growth of ODL institutions in developing countries (Udegbe, 2012). This is due to the development of Information and communication technology (ICT) particularly internet-based technology (Ali, 2011). Because of the use of ICT particularly the internet, ODL is described using the terms e-learning and online learning (Moore and Kearsley, 2005).

Also, ODL took root in many countries as a means to resolve political compulsions as also to fulfill the aspirations of different sections of the people who had missed educational opportunities, not as a matter of individual choice but as compulsions of social and cultural contexts (Rao, 2011). ODL offers flexibility and teaching approaches that are centered on the student with regard to content, time, place, pace of learning, method of instruction and nature of assessment (Wei, 2010). ODL is characterized by learners' freedom of selection of what, when and where to learn (Sharma and Gupta, 2012). Thus, the objective of ODL is to enhance the opportunities that support education for all and life-long learning (Ofoegbu, 2009).

Unlike in conventional educational institutions, teachers and the students are isolated by distance and time in ODL (Udegbe, 2012). Due to distance and lack of contact with students in ODL, there has been a higher failure rate and low graduation rate. This has led government to exert strong pressure on ODL educational institution to improve student success (Subotzky and Prinsloo, 2011). As a result, ODL institutions provide students support (Wei, 2010). University such as UNISA have provided libraries, computer labs, internet-based support, free e-mail, online tutors and learning centres for face-to-face tutorial in order to support students. Although discontinued in 2011, UNISA had a contact centre through which students can call for help with their study related matters.

\subsection{Definition of Open distance learning}

There are several definitions of ODL. Bouras et al. (1998) define ODL as the process of learning with the use of telematics that is the combination of telecommunication, information and multimedia technology and its services (Bouras et al. 1998). This definition is limiting ODL to ICT and is therefore not inclusive of what ODL is all about. Moore and Tait (2002) define ODL as approaches that focus on opening access to education and training provision, freeing learners from the constraints of time and place, and offering flexible learning opportunities to individuals and groups of learners. Although it does not mention ICT, this definition is comprehensive. Kurtz, Amichai-Hamburger and Kantor (2009) define $\mathrm{ODL}$ as an interactive teaching-learning process, in which at least part of it is done online by means of text/audio/video. This definition does not differentiate ODL institutions and traditional/conventional institutions because it does not address the distance between teachers and learners. Having considered these definitions and for the purpose of this study, ODL is defined as a system that offer education without boundaries of knowledge content, time and place through the help of ICT and provide learner support to ensure learner success.

UNISA is the largest ODL institution in Africa and the longest standing dedicated distance education university in the world. UNISA enrols nearly one-third of all South African students. Founded in 1873 as the University of the Cape of Good Hope, the institution became the first public university in the world to teach exclusively by means of distance education in 1946. Throughout the years, UNISA was the only university in South Africa to have provided all people with access to education, irrespective of race, colour or creed. UNISA offer an unparalleled range of study choices, ranging from short courses and certificate programmes to three and four year degrees and diplomas, to over 350 000 students almost every year (http://www.unisa.ac.za/Default.asp?Cmd=ViewContent\&ContentID=17765).

According to Pityana (2009), UNISA has the highest foreign student enrolment figures in Africa and provides its teaching and learning and administrative services worldwide. He further indicate that UNISA has a direct impact on higher education in South Africa, and increasingly, on the Continent, and its successes or failures will be reflected similarly. Pityana (2009) acknowledges that UNISA as an ODL institution has challenge which is to endeavor not only to ensure access and affordability but to address national anxieties about drop-out, success and throughput rates. Scott, Yeld and Hendry (2007) found that at UNISA only 30\% of the 2000 first-time student cohort had graduated within five years. Moreover, with a further $14 \%$ still registered, $56 \%$ of the cohort had therefore discontinued their studies. UNISA is 
experiencing rapid increase in enrolment and causes operational problems such as late deliveries of study materials (Subotzky and Prinsloo, 2011).

\section{Entrepreneurial Intentions}

Entrepreneurship is a major contributor to economic growth of a country (Gurel, Altinay and Daniele, 2010). Entrepreneurs create jobs, enforce competition, create innovative products and service and this leads to economic growth (Smith, Collins and Hannon, 2006). Entrepreneurs' entrepreneurial behaviours are intentional and not accidental (Southon and West, 2005). Entrepreneurial intentions are the first step in the entrepreneurship process (Ajzen, 1991). Also, it is widely accepted that entrepreneurial intentions are the best predictor of entrepreneurial behaviours (Kirby, 2004). Many researchers have been dedicated their research for the establishment of the factors that influence entrepreneurial intentions. This is because it easier to measure entrepreneurial intentions than entrepreneurial behaviour (Ajzen, 1991). For easy understanding of entrepreneurial intension, there is a need to define both entrepreneurship and entrepreneur.

Due to its relation to economic and behavioural dimensions, scholars are finding it difficult to define entrepreneurship (Politis, 2005). However, it is agreed that entrepreneurship enables individuals to develop their talents and creativity to achieve their dreams, and to acquire more independence and a certain feeling of freedom (Mars and Garrison, 2009). According to Koe, Sa'ari, Majid and Ismail (2012), entrepreneurship is synonymous to self-employed. There are many definitions of entrepreneurship. It is not the purpose of this research to construct a definition of entrepreneurship. However, the following are some of the definition of entrepreneurship:

- An ability to welcome and support innovation brought by external factors by welcoming change, taking responsibility for one's actions, positive or negative, to finish what has been started, to know the direction to set objective and the way to achieve them, and have the motivation to succeed; it is also including the willingness to change the self to deal with the challenges (Shapero and Sokol, 1982).

- Creation of new enterprise (Low and MacMillan, 1988)

- The novel business enterprise formation and entrepreneurial deed in creating business enterprise (Shane and Venkataraman, 2000).

- A role that individuals undertake to create organizations (Gartner, 2001).

- To create a new economic organization by innovation under risk and uncertain environment (Dollingers, 2003).

- A dynamic process of vision, change and creation (Ahmed, Hafiz, Kashif and Nadeem, 2010).

- The discovery, evaluation and exploitation of opportunities to create future goods and services by the natural individual through the creation of a new business venture (Saravanakumar and Saravanan, 2012).

The entrepreneur is the main actor in the entrepreneurship process. Since defining the entrepreneur is a great challenge (Kloftsen, 2000) there is no generally agreed upon definition of an entrepreneur (Kirby, 2004). Having followed the origin of the term, which stems from the French verb entreprendre meaning to undertake, Kirby (2004) went on to simply define an entrepreneur as someone who undertakes to make things happen, and does. Other authors (Smith, Collins and Hannon, 2006) see an entrepreneur as someone who takes calculated risks, embraces innovation and takes decisions based on their judgment. Zhao, Seibert and Lumpkin (2010) simply define an entrepreneur as as the founder, owner, and manager of a small business. Sajjad, Shafi and Dad (2012) broadly define an entrepreneur as an individual who runs a business with new idea or adding value in existing idea entrepreneur is a creator, risk taker who brings change in environment, with the help of technology, effective organization trained employees, and gets maximum benefit.

With regard to behavioural requirements of entrepreneurs Vincett and Farlow (2008) suggest that, there are 14 behaviours that are required by the entrepreneur, depending upon the situation in which he/she is to be found. They indicate that these behaviours can be learned. These behaviours are classified according to the following criteria: (1) total commitment, determination and perseverance; (2) drive to achieve and grow; (3) orientation to goals and opportunities; (4) taking initiative and personal responsibility; (5) showing awareness and a sense of humour; (6) seeking and using feedback; (7) having an internal locus of control; (8) showing tolerance of ambiguity, stress and uncertainty; (9) calculated risk-taking and risk-sharing; (10) having a low need for status and power; (11) demonstrating integrity and reliability; (12) demonstrating decisiveness, urgency and patience; (13) learning from failure; and (14) being a team builder and hero maker.

Ajzen (1991) defines intentions as indications of how hard individuals are willing to try, of how much of an effort they are planning to exert, to perform the behaviour. However, just like entrepreneurship and entrepreneur, entrepreneurial intention does not have a standardised definition. Several definitions of entrepreneurial intentions exist in 
the literature. The following are some of the definitions of entrepreneurial intentions:

- The expressed behavioural intention to become an entrepreneur (Bird and Jelinek, 1988).

- The conscious state of mind that precedes action and directs attention towards a goal such as starting a new business (Krueger and Carsrud, 1993).

- The intention to start a new business (Pillis and Reardon, 2007).

- The action of an individual's attitudes toward the outcomes of that actions and individuals self efficacy (Douglas and Fitzsimmon, 2008).

- A conscious state of mind that directs attention and therefore experience and action toward a specific object or pathway to achieve it (Hamidi, Wennberg and Berglund, 2008).

- The intention of an individual to set up a new business venture sometime in the future (Thompson, 2009).

Although there are several definitions of entrepreneurial intentions, most researchers agree that entrepreneurial intentions are predictor of entrepreneurial behaviour (Ajzen, 1991). Researchers also acknowledge that there are many factors that influence entrepreneurial intentions and these factors vary from culture to culture and from country to country (Sajjad, Shafi and Dad, 2012). Entrepreneurial intentions depend on external factors such as the presence of an unfavourable economic environment or lack of regular employment options (Ghatak, Morelli and Sjostorm, 2007). Krueger, Reilly and Carsrud (2000) attest that even when people embark on entrepreneurship due to losing job, there has been evidence indicating tendency and interest in having a dependent business long time ago. According to Zhao, Seibert and Lumpkin (2010), openness to experience will be positively related to entrepreneurial intentions. De Clercq, Honig and Martin (2012) found knowledge and passion for work to have a greater influence on entrepreneurial intentions. Zain, Akram and Ghani (2010) argue that entrepreneurial intention involves inner guts, ambition and feeling to stand on one's feet. Koea, Sa'arib, Majidc and Ismaild (2012) state that understanding factors that influence entrepreneurial intentions is important because entrepreneurial behaviours are a result of intentions.

Several entrepreneurial intentions model have designed be scholars to test the factors that influence intentions. The following are some of the models of entrepreneurial intentions identified in the literature:

- Entrepreneurial event model (Shapero, 1982);

- Theory of planned behaviour (Ajzen, 1991);

- Entrepreneurial attitude orientation (Robinson et al. 1991);

- Intentional basic model (Krueger and Carsrud, 1993);

- Entrepreneurial potential model (Krueger and Brazeal, 1994); and

- Davidsson model (Davidsson, 1995).

Of the above models, Shapero's Model of Entrepreneurial Event (SEE) and Ajzen's Theory of Planned Behaviours (TPB) have been used by many researchers to test students' intentions to start a business venture (Nabi, Holden and Walmsley, 2010). However, TPB has been widely used (Miralles, 2012) and for this reason it will adopted for the purpose of this study. According to Ajzen (1991), intentions are a greater predictor of behaviours and the stronger the intention to engage in behaviour, the more likely it will be performed. TPB is used to explain an individual's intention to perform a given behaviour (Ariff, Bidin, Sharif and Ahmad, 2010). According to Ajzen (1991), there are three antecedents of intentions, namely personal attitude, subjective norms and perceived behavioural control. These antecedents of intentions are depicted in figure 2.

According to Kautonen, Tornikoski and Kibler (2011), attitude toward the behaviour refers to the degree to which a person has a favorable or unfavorable evaluation or appraisal of the behaviour in question, subjective norm refers to the perceived social pressure to perform or not to perform that behaviour and perceived behavioural control refers to the perceived ease or difficulty of performing the behaviour. The central factor in the TPB is the individual's intention to perform a given behaviour (Ajzen, 1991). According to this model, attitude toward behaviour, subjective norms or perceived behavioural control directly influence intentions which influence behaviours. There is a significant relationship between attitude and entrepreneurial intention (Fini, Grimaldi, Marzocchi and Sobrero, 2009). Although some researchers found subjective norm to be a significant predictor of entrepreneurial intentions, some found it to be a weaker predictor of entrepreneurial intentions (Kautonen, Tornikoski and Kibler, 2009; Shook and Bratianu, 2010; Sommer and Haug, 2011). Perceived behavioural control is a strongest predictor of entrepreneurial intentions (Shook and Bratianu, 2008; Sommer and Haug, 2011). 


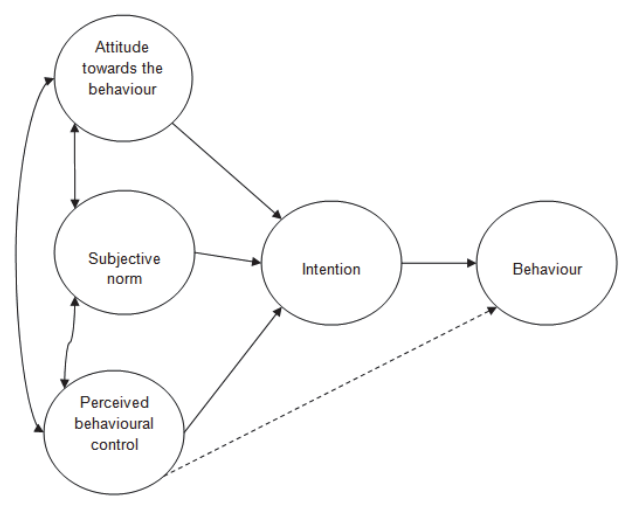

Figure 2: Theory of planned behaviour (Ajzen, 1991)

\section{Research Methodology}

A survey was undertaken to collect data from Administrative Practice students registered at UNISA for the academic year 2011. Throughout the years, UNISA was perhaps the only university in South Africa to have provided all people with access to education, irrespective of race, colour or creed. UNISA is the largest open distance learning institution in Africa and the longest standing dedicated distance education university in the world. UNISA enrols nearly one third of all South African students. Moreover, UNISA enrols over 350000 students every year (http://www.unisa.ac.za /Default.asp?Cmd=ViewContent\&ContentID=17765). A questionnaire was used to collect data from the students. Openended and closed-ended questions were incorporated in the questionnaire. In addition, a Likert Scale was used to establish the extent to which students agree or disagree to different statements of interest. The questionnaire was sent to all students (330) registered for Administrative Practice via e-mail. Students were requested to attach the completed questionnaire to their project and submit them all together. Those who failed to attach the questionnaire to their project scanned and e-mail or faxed the questionnaire to the lecturer. Of the 330 students, only 270 were admitted to the examination allowing them an opportunity to submit their project. Only 97 usable questionnaires were received from the students. This led to a response rate of $35.93 \%$. The internal data reliability was calculated to be 0.857 (Cronbach' Alpha). This shows that this research is very reliable.

\section{Research Results}

Of the 97 students, $19.6 \%$ were male and $80.4 \%$ were female. The racial groups were represented as follows: African (69.1\%); Asian (3.1\%); Coloured (9.3\%); and White (18.6\%). The students were in the following age groups: 20 -29 years (36.1\%), $30-39$ years (44.3\%) and 40 years or older (19.6\%). Of the 97 students, $51.5 \%$ were single, $43.3 \%$ married and $5.2 \%$ divorced.

All the students who returned the questionnaire managed to find work placement. $38.1 \%$ of the students found the placement themselves; $4.1 \%$ were assisted by the university to find placement; $3.1 \%$ were placed in a family business; $4.1 \%$ were employed by at the university; and $50.5 \%$ already employed. Of the 97 students, $56.7 \%$ indicated that two months was long enough for the completion of the project whereas $43.3 \%$ indicated that it was not. Those who indicated that two month was not long enough gave the following summarised reasons:

- It requires time to adjust to the work environment (4.8\%)

- It is difficult to complete the project if you are registered for many other modules (2.4\%)

- There is so much to be learned (83.3\%)

- Mentors are not always available to assist because of their tight schedule (9.5\%)

When asked what the suitable time frame in months should be, $6.2 \%$ of the students chose three months; $19.6 \%$ chose four months; $1 \%$ chose five months; 10.3 chose six months; $2.1 \%$ chose seven months; and the remaining 60.8 happy with two months. Students were placed in the following industries: public service (11.3\%); transport, storage and communication (8\%); educational services (8.2\%); agriculture, forestry and fishing (7.2\%); financing, insurance, real estate and business services (7.2\%); medical, dental, other health and veterinary and business services (7.2\%); social 
and related community services (7.2\%); mining and quarrying (5.2\%); eelectricity, gas and water (4.1\%); law (3.1\%); agencies and other services (3.1\%); Food, beverages and tobacco (2.1\%); Paper, printing and publishing (2.1\%); machinery and related items (2.1\%); manufacturing (2.1\%); construction (2.1\%); retail trade $(2.1 \%)$; safety and security (1\%); office automation (1\%); IT services (1\%); government agency (1\%); equipment programme sector (1\%); laundry (1\%); commercial and industrial; auditing (1\%); wood, wood products and furniture (1\%); chemicals, and chemical, rubber and plastic products (1\%); catering and accommodation (1\%); and long-term insurers (1\%).

As it pertain the project content; $81.4 \%$ agreed that the project covers everything about the current administrative practice; $89.6 \%$ agreed that the project deals with relevant administrative duties; $90.7 \%$ agreed that the project prepares students for the work environment; $82.4 \%$ indicated that the project was challenging; $85.6 \%$ indicated that the project makes them want to know about the organisation they were place in; $53.6 \%$ indicated that the project is relevant to the workplace; $68.1 \%$ indicated that the project covers things that are happening in the workplace; and $61.8 \%$ indicated that the project should not be changed. The following additional comments were provided concerning the project content:

- It develops skills such as communication, team work; sending of e-mails and report writing, punctuality and attendance, and develops awareness to the workplace culture;

- It gives an opportunity to get out of the comfort zone;

- It helps students to think critically;

- It prepares students for the work environment;

- It's difficult to find placement;

- It's difficult to get information from larger organisation;

- Some organisations don't have needed equipment;

- Students got employed due to experiential learning; and

- University must align the course content with what companies are doing.

Of the 97 students, 75 were already employed before starting the experiential learning project. Twenty two were unemployed before starting with the project. None of these students had businesses before doing the experiential learning project. Of the 22 students who were unemployed before starting the project, 7 (31.8\%) indicated that they will start a business soon due to the experiential learning project. Of the 75 students who were employed before, 25 (33.3\%) of the students indicated that they will start a business soon due to the experiential learning project. Overall, 32 (33\%) students indicated that they intend to start a business due to this experiential learning project in business management. Therefore, experiential learning in business management in an ODL institution influences entrepreneurial intentions to a lesser extent.

The following strong positive linear correlation was established between marital status and entrepreneurial intentions: Pearson's $r$ for variable marital status and entrepreneurship intentions was 0.797 . Thus, there was a strong positive linear association between these two variables. Sixteen out of fifty (32\%) single students indicated that they intend to start a business in the future due to the experiential learning course in administrative management. Twenty seven out of fifty (54\%) indicated that they would not start a business while $7(14 \%)$ out of fifty were indecisive. Thirteen out of forty two (31\%) married indicated that they would start a business in the future due to the experiential learning course in administrative management while twenty nine out of fifty $(69 \%)$ indicated that they would not. Of the five divorced students, one (20\%) was indecisive, one (20\%) disagreed and three $(60 \%)$ indicated that they would start a business in the future due to the experiential learning course in administrative management. Thus the majority of divorced people intend to start a business as a result of this course. A lesser percentage of married people also intend to start a business as result of this course. The majority of young people do not intend to start a business.

\section{Discussion}

The majority of the respondents to this research were women. This confirms the current trend that there are more women in office administration. Men are rarely worked in office administration. It is no surprise that the majority of respondents were Africans because the current trend reveals that most people in office administration are Africans. Most of the respondents were between the age of 20 and 40 years. This indicates that people move from administrative positions to management as they grow older. The majority of the respondents were single.

The majority of the respondents were already employed before registering for the course. This could mean that most the students that register in open distance learning are working. The majority of the students indicated that two months was enough to complete the project. This means that the project period should be kept at two months. The majority of the students were placed in public service industry. Therefore universities who incorporate experiential 
learning in their courses should have a good relationship with the public service industry.

The majority of the students indicated that the project covers everything about the current administrative practice; the project deals with relevant administrative duties; the project prepares students for the work environment; the project was challenging; the project makes them want to know about the organisation they were place in; the project is relevant to the workplace; the project covers things that are happening in the workplace; and the project should not be changed.

The findings reveal that this experiential learning course has an influence on entrepreneurial intentions to a lesser extent. One out of every three of working students indicated that they would start a business as a result of this course. The majority of the students that were not working indicated that they would not start a business. One third of all students indicated that they would start a business because of this course.

The findings revealed a positive linear relationship between marital status and entrepreneurial intentions. The majority of single students indicated that they would not start a business as a result of this course. Almost one third of married students indicated that they would start a business because of this course. The majority of divorced students indicated that they would start a business because of this course. Thus the course had a greater influence on the entrepreneurial intentions of divorced students.

\section{Conclusion}

Entrepreneurial intentions do not happen by accident but triggered by something. It has been conclude that entrepreneurship courses triggers entrepreneurial intentions (Southon and West, 2005). Moreover, it has been concluded that action-oriented entrepreneurship courses trigger entrepreneurial intentions to a greater extent (Dhliwayo, 2008). However, evidence is lacking about the influence of other business management experiential learning courses on entrepreneurial intentions.

This research reveals that this course in administrative management influences the entrepreneurial intentions of the students to a lesser extent. This research also reveals that marital status has an influence on entrepreneurial intentions of students. Divorced students were influenced to greater extent by the course to start businesses. Therefore, this course influences the entrepreneurial intentions of the students to a lesser extent. This implies that incorporation of experiential learning in other business management courses may lead to entrepreneurial intentions but to a lesser extent. This research was limited to students who were registered for the course in administrative management at UNISA. A further research should be conducted to establish whether students started businesses because of this course.

\section{Acknowledgements}

This work is based on the research supported by the National Research Foundation. The authors would also like to acknowledge the University of South Africa (South Africa) for the funding and support without which this research would not have been possible.

\section{References}

Ahmed, I.H., Hafiz, M. A., Kashif, R., \& Nadeem S. (2011). Factors influencing intention to create new venture among young graduates, Africa Journal of Business Management, 5(1), 121-127.

Ajzen, I. (1991). Theory of planned behavior. Organizational Behavior and Human Decision Processes, 50 (1), $179-211$

Ali, E.A. (2011). Challenges before open and distance learning: global perspective and the experience of open university Malaysia. International Conference cum Workshop: Vardhaman Mahaveer Open University, Kota, Rajasthan, India, 7-9 March 2011.

Arasti, Z., Pasvishe, F.A. \& Motavaseli, M. (2012). Normative Institutional Factors Affecting Entrepreneurial Intention in Iranian Information Technology Sector. Journal of Management and Strategy, 3(2), 16-24.

Ariff, A.H.M., Bidin, Z., Sharif, Z. \& Ahmad, A. (2010). Predicting entrepreneurship intention among Malay university accounting students in Malaysia. UNITAR E-journal, 6(1), 1-10.

Bird, B. and Jelinek, M. (1988). The operation of entrepreneurial intentions. American Journal of Small Business, 13(2): 21-30.

Bouras, C., Destounis, P., Garofalakis, J., Gkamas, A., Sakalis, G., Sakkopoulos, E., Tsaknakis, J. \& Tsiatsos, T. (2000). Efficient webbased open and distance learning services. Telematics and Informatics, 17(1), 213-237.

Clark, J. \& White, G.W. (2010). Experiential learning: a definitive edge in the job market. American Journal of Business Education, 3(2), 115-118.

Davidsson, P. (1995). Culture, structure and regional levels of entrepreneurship. Entrepreneurship and Regional Development, 7(1), 4162.

De Clercq, D., Honig, B. \& Martin, B. (2012). The roles of learning orientation and passion for work in the formation of entrepreneurial intention. International Small Business Journal, 0(0), 1-25. 
Dhliwayo, S. 2008. Experiential learning in entrepreneurship education: a prospective model for South African tertiary institutions. Education + Training, 50(4), 329-340.

Dollingers, M. J. (2003). Entrepreneurship: strategies and resources. (3rd ed.). NJ: Prentice Hall.

Douglas, E.J. \& Fitzsimmons, J.R. (2008) Individual Intentions Towards Entrepreneurship vs Intrapreneurship. In Gillin, L. Murray (Ed.) 5th AGSE International Entrepreneurship Research Exchange, 5 - 8 February, 2008, Melbourne, Australia.

Fini, R., Grimaldi, R., Marzocchi, G.L. and Sobrero, M. (2009). The foundation of entrepreneurial intention, conference proceedings in Summer Conference 2009, June 17-19, 2009, Frederiksberg, Denmark.

Gartner, W.B. (2001). Is there an elephant in entrepreneurship research? Blind assumptions in theory development. Entrepreneurship Theory \& Practice, 25(4), 27-39.

Ghose, N. (2010). Enhancing Global Competitiveness Through Experiential Learning: Insights Into Successful Programming. American Journal of Business Education, 3(7), 1-6.

Gurel, E., Altinay, L. \& Daniele, R. (2010). Tourism students' entrepreneurial intentions. Annals of Tourism Research, 37(3), 646-669.

Hamidi, D., Wennberg, K. \& Berglund, H. (2008). Creativity in entrepreneurship education. Journal of Small Business and Enterprise Development, 15(2), 304-20.

http://www.unisa.ac.za/Default.asp?Cmd=ViewContent\&ContentID=17765 (accessed 22 November 2012)

Hynes, B. \& Richardson, I. (2007). Entrepreneurship education: a mechanism for engaging and exchanging with the small business sector. Education + Training, 49(8/9), 732-744.

Jennings, C. \& Wargnier, J. (2010). Experiential learning - a way to develop agile minds in the knowledge economy? Development and Learning in Organizations, 24(3), 14-16.

Kautonen, T., Tornikoski, E.T., \& Kibler, E. (2011). Entrepreneurial intentions in the third age: the impact of perceived age norms. Small Business Economics, 37(2), 219-234.

Khodabakhshi, S. \& Talebi, K. (2012). Evaluating the Role of Entrepreneurial Self-Efficacy on Entrepreneurial Intention of Tehran University (Case Study of Engineering Campus). Journal of Education and Vocational Research, 3(3), 82-88.

Kirby, D.A. (2004). Entrepreneurship education: can business schools meet the challenges? Education + Training, 46(8/9), 510-519.

Koe, W., Sa'ari, J.R., Majid, I.A. \& Ismail, K. (2012). Determinants of Entrepreneurial Intention Among Millennial Generation. Social and Behavioral Sciences, 40(1), 197-208.

Kloftsen, M. (2000). Training entrepreneurship at universities: a Swedish case. Journal of European Industrial Training, 24(6), 337-344.

Kolb, D. (1984). Experiential learning: Experience as the source of learning and development. Englewood Cliffs, NJ: Prentice Hall.

Krueger, N.F. \& Brazeal, D. (1994). Entrepreneurial potential and potential entrepreneurs. Entrepreneurship Theory and Practice, 18(3), 91-104.

Krueger, N.F. \& Carsrud, A.L. (1993). Entrepreneurial intentions: Applying the theory of planned behaviour. Entrepreneurship \& Regional Development, 5(4), 315-330.

Krueger, N.F., Reilly, M.D.R. and Carsrud, A.L. (2000), Competing models of entrepreneurial intentions. Journal of Business Venturing, 15(1), 411-432.

Kurtz, G., Amichai-Hamburger, Y. \& Kantor, J. (2009). Psychosocial Well-Being of Israeli Students and Attitudes toward Open and Distance Learning. The International Review of Research in Open and Distance Learning, 10(2). http://www.irro dl.org/index.php/irrodl/article/viewArticle/593/1212 (accessed 12 December 2012).

Low, M. B., \& MacMillan, I. C. (1988). Entrepreneurship: past research and future challenges. Journal of Management, 14(1), 139-161.

Mars, M.M. \& Garrison, S. (2005) Socially-oriented ventures and traditional entrepreneurship education models: a case review. Journal of education for business, 84(5), 290-296.

Moore, C., Boyd, B.L. \& Dooley, K.E. (2010). The Effects of Experiential Learning with an Emphasis on Reflective Writing on Deep-Level Processing of Leadership Students. Journal of Leadership Education, 9(1), 36-52.

Moore, M.G. \& Kearsley, G. (2005). Distance education: A systems view. (2nd ed.). Belmont, CA: Wadsworth.

Moore, M. \& Tait, A. (2002). Open and Distance Learning: Trends, Policy and Strategy Considerations. Paris: UNESCO.

Nabi, G., Holden, R. \& Walmsley, A. (2010). Entrepreneurial intentions among students: towards a re-focused research agenda. Journal of Small Business and Enterprise Development, 17(4), 537-551.

Nevin, T. (2001). Business skills in jail. African Business, 41-42.

Nga, H.K.J., Shamuganathan, G., 2010. The influence of personality traits and demographic factors on social entrepreneurship start up intentions. Journal of Business Ethics 95(1), 259-260.

Ofoegbu, I.F. (2009). Female access to basic education: a case for open distance learning (ODL). Edo Journal of Counseling, 2(1), 4657.

Pillis, E., \& Reardon, K. K. (2007). The influence of personality traits and persuasive messages on entrepreneurial intention: A crosscultural comparison. Career Development International, 12(4), 382-396.

Pityana, N.B. (2009). Open distance learning in the developing world: trends, progress and challenges. 23rd ICDE World Conference on Open Learning and Distance Education. "Flexible Education for All: Open - Global - Innovative" 7 - 10 June 2009, Maastricht, the Netherlands.

Politis, D. (2005). The process of entrepreneurial learning: a conceptual framework. Entrepreneurship theory and practice, 29(4), 399424.

Rao, P.K. (2011). Enrolment, success rate and expenditure in open and distance learning - the experience of the first Open University in India. Journal of open schooling, 2(1), 34-43. 
Robinson, P.B., Stimpson, D.V., Huefner, J.C. \& Hunt, H.K. (1991). An attitude approach to the prediction of entrepreneurship. Entrepreneurship Theory and Practice, 15(1), 13-31.

Sajjad, S.I., Shafi, H. \& Dad, A.M. (2012). Impact of culture on entrepreneur intention. Information Management and Business Review, 4(1): $30-34$.

Saravanakumar, M. \& Saravanan, S. (2012). Entrepreneurship education shaping students entrepreneurial intention. European Journal of Social Sciences, 33(2): 317-323.

Scott, I., Yeld, I., \& Hendry, J. (2007). A case for improving teaching and learning in South African higher education. Pretoria: The Council on Higher Education.

Shane, S. \& Venkataraman, S. (2000). The promise of entrepreneurship as a field of research. Academy of Management Review, 25(1), 217-226.

Shapero, A. (1982). Social Dimensions of Entrepreneurship. NJ: Prentice-Hall, Englewood Cliffs.

Shapero, A. \& Sokol, L. (1982). Social dimensions of entrepreneurship. In: Kent CA, Sexton DL and

Sharma, S. \& Gupta, S. (2012). The virtual classroom: the role of ICT in open and distance learning. International Journal of Computer, Communication and Emerging Technology, 1(1), 8-12.

Shook, C.L. \& Bratianu, C. (2010). Entrepreneurial intent in a transitional economy: an application of the theory of planned behavior to Romanian students. International Entrepreneurship Management Journal, 6(1), 231-347.

Smith, A.J. Collins, L.A. \& Hannon, P.D. (2006). Embedding new entrepreneurship programmes in UK higher education: Challenges and considerations. Education + Training, 48(8/9), 555-567.

Sommer, L. \& Haug, M. (2011), Intention as a cognitive antecedent to international entrepreneurship: understanding the moderating roles of knowledge and experience. International Entrepreneurship Management Journal, 7(1), 111-142.

Southon, M. \& West, C. (2005). Enterprise gets lead role. Director, 59(4), 24.

Subotzky, G. \& Prinsloo, P. (2011). Turning the tide: a socio-critical model and framework for improving student success in open distance learning at the University of South Africa. Distance Education, 32(2), 177-193.

Thompson, E.R. (2009), Individual entrepreneurial intent: construct clarification and development of an internationally reliable metric. Entrepreneurship Theory and Practice, 3(3), 669-94.

Udegbe, B. (2012). Attitudes of prospective human resource personnel towards distance learning degrees. Online Journal of Distance Le arning Administration, 15(1). http://www.westga.edu/ distance/ojdla/spring151/udegbe.html (accessed 12 December 2012).

Vesper, J., Bishara, R. \& Reeves, T. (2010). A case study in experiential learning: pharmaceutical cold chain management on wheels. Journal of Continuing Education in the Health Professions, 30(4), 229-236.

Vincett, P.S. \& Farlow, S. (2008). Start-a-business: an experiment in education through entrepreneurship. Journal of small business and enterprise development, 14(2), 274-288.

Wei, R. (2010): China's radio and TV universities: reflections on theory and practice of open and distance learning, Open Learning: The Journal of Open, Distance and e-Learning, 25(1), 45-56.

Zhao, H., Seibert, S.E. \& Lumpkin, G.T. (2010). The relationship of personality to entrepreneurial intentions and performance: a metaanalytic review. Journal of Management, 36(1), 381. 